\title{
TO ARRANGE OR NOT: MARRIAGE TRENDS IN THE SOUTH ASIAN AMERICAN COMMUNITY
}

\author{
Farha Ternikar \\ Le Moyne College
}

\section{Introduction ${ }^{1}$}

The idea of the arranged marriage has always seemed "exotic" yet has fascinated the American public. Recent media coverage of arranged marriages is evident in popular periodicals such as the New York Times Online (August 17, 2000) and Newsweek (March 15, 1999). Foner highlights that the arranged marriage is an example of "the continued impact of premigration cultural beliefs and social practices" that South Asian immigrants have transported to the United States (Foner 1997, 964). She offers an interpretive synthesis by showing that "[n]ew immigrant family patterns are shaped by cultural meanings and social practices that immigrants bring with them from their home countries as well as by social, economic, and cultural forces in the United States" (Foner 2005, 157).

1 Acknowledgements: This paper could not have been completed without the generous support and comments of the following: Prema Kurien, Fred Kniss, Paul Numrich, Frank Ridzi, Travis Vande Berg, Judith Wittner, and Rhys Williams. 


\section{Ethnic Studies Review Volume 31}

This article explores the marriage options that South Asian immigrants have and how religion influences these options. The choice in the South Asian American community, once between the arranged marriage and the "love marriage," now includes additional options as new immigrants negotiate new ways of finding marriage partners. These methods vary depending on religious tradition, family influence and ethnic community ties. These new methods are examples of ways that second-generation immigrants try to preserve some traditions from their parents' generation while creating new traditions. My research finds that courtship and marriage norms in the South Asian immigrant community are often reinforced by traditional religious ideology, but they vary by religious tradition. For example, a conservative Swaminarayan Hindu temple may arrange marriages through family networks to ensure religious and racial endogamy, while a liberal Indian Catholic church may allow dating in its community as an appropriate method of meeting potential marriage partners, or a conservative mosque may advocate arranged or semi-arranged marriages in hopes of maintaining modesty and chastity norms ${ }^{2}$.

This study is significant because there is a dearth of research on religion and South Asian immigrant families. Though significant studies have made great contributions to the study of South Asian immigrants, there is no detailed research on how religion and ethnicity both play an important role in the construction of the new ways that second-generation immigrants negotiate tradition, family, and finding personal happiness in the marriage process ${ }^{3}$. This research explores how families, religious traditions, and ethnic communities influence how members of this new ethnic community find marriage partners by the creation of new marital norms.

\section{Methods}

In this article I draw on data from observations and fifty indepth interviews from 2001-2004 I collected as a researcher for the

2 Endogamy remains a significant issue in these three religious congregations (Kniss and Numrich 2007).

3 Rangaswamy 2000, Leanard 2003, Lessinger 1995, Purkayastha 2005, Foner 1997 
Religion, Immigration and Civil Society in Chicago (RICSC) project ${ }^{4}$. I interviewed congregation leaders, school administrators, teachers and lay members at the RICSC sites. ${ }^{5} \mathrm{I}$ also attended meetings of the South Asian Student Association, the Muslim Students Association, and the Hindu Student Organization at Chicago college campuses. I made my initial contacts at these student organizations via email list-servs. In addition to email contacts, I was also able to approach members from these groups at bake sales, informal social gatherings, and meetings.

\section{Description of Sample: South Asian Immigrants in Chicago}

Overall, my sampling techniques were a combination of convenience and snowball sampling. I maximized my range of sampling rather than used random sampling since I wanted to develop a comparative framework. Convenience sampling is valuable as it offers depth and contributes to theory building (Weiss 1994, 26). Snowball sampling is useful because it taps into social networks (Macdonald and Tipton 1993).

My sample consisted of forty-three Indian immigrants, six Pakistani immigrants, and one Bangladeshi immigrant. Eleven were first generation immigrants who were born and raised in South Asia, and thirty-nine were second-generation immigrants. I had a larger number of female respondents (37) than male respondents (13). This was most likely because of two factors. Initially, congregants at Islamic Foundation and BAPS Swaminarayan temple preferred same-sex interviewers. As a result, I interviewed mostly women at these sites. When I did interview men for this project, they were hesitant to speak at length about marriage and dating.

A limitation of my sample is that it consists of predominantly middle-class and professional immigrants, and this sample has

4 The Religion, Immigration and Civil Society in Chicago (RICSC) was a threeyear project of Loyola University Chicago's McNamara Center for the Social Study of Religion, directed by Paul Numrich and Fred Kniss, and funded by The Pew Charitable Trusts.

5 See Kniss and Numrich 2007 for detailed descriptions of all of the research sites. The RICSC project examined immigration and religion at 16 religious sites in the Chicago area. I conducted interviews at the Muslim and Hindu sites including Islamic Foundation and BAPS Swaminaryan. 


\section{Ethnic Studies Review Volume 31}

a large percentage of college-educated respondents. Most firstgeneration immigrants whom I interviewed were professionals, and all of the second-generation immigrants were college students or had completed college. This was largely because my research sites were two religious congregations in a Chicago suburb, one city congregation close to a university, and two Chicago universities.

This sample was religiously diverse for comparison purposes. I wanted to examine how marriage patterns vary among Hindu, Muslim and Christian South Asian immigrants. However, I was not able to obtain an equal number of Hindu, Muslim and Christian South Asian interviews. I interviewed fifteen Hindu immigrants, twenty-six Muslim immigrants, and nine Christian immigrants. I was easily able to find a larger sample size of consenting Muslim respondents because of my insider status as a second-generation Indian Muslim and my familial ties to the Muslim immigrant community. All of my Christian respondents were a result of snowball sampling from other Indian college students.

\section{Importance of Marriage in South Asian Immigrant Families and Community}

Marriage is the cornerstone of South Asian immigrant families and community life (Kniss and Numrich 2007). Married individuals are given a higher status in South Asian community than those that are unmarried. In addition, immigrant children are not looked at as adults until they have married, regardless of age and professional accomplishments as Farheen ${ }^{6}$, a 25 year old Muslim Indian woman, explained: "You are just a kid in the eyes of the community till you get married... Girls that are married but not even graduated from college and younger than me seem to be given more respect at community parties." As a result, a large amount of pressure is put on South Asian immigrant children to marry. The importance of marriage is also reinforced by both South Asian immigrant and ethno-religious communities.

Entire ethnic communities make great efforts to find appropriate

6 All names of participants in this study have been changed. Names that I have used in this paper are pseudonyms that reflect the respondents' ethnic and religious backgrounds. I relied on Wittner's model of field-work to gather data and conduct interviews (Warner and Wittner 1998) 
mates for single South Asian immigrants and have developed a "marriage economy" (Foner 1997). Marriage bureaus, matrimonial advertisements, and matchmakers catering to the South Asian immigrant community are quite common in urban areas such as Chicago or New York (Kniss and Numrich 2007). These services put immigrants in touch with families of potential mates. Parents take out advertisements for their children in South Asian periodicals. Matchmakers also organize formal and informal social events for young single South Asian immigrants. The respondents in my study spoke of a singles mixer in the basement of a mosque, dances sponsored by an Indian church, and the Hindu matchmaker at the temple. These events and institutions signify the importance of marriage in the South Asian American community ${ }^{7}$.

Within the South Asian immigrant community, there are also many informal networks that assist in making introductions. Some of these networks are loosely based in religious congregations; others are through groups of family friends. Sobia, an Indian Muslim woman, explained that her parents were very active in the local Hyderabradi community. They hosted large dinners in her parents' house often inviting families that had eligible sons. Sobia and Sannah both mentioned that "desi" ${ }^{\prime \prime}$ weddings were a site that social networking happened for the purpose of introducing families that have marriageable children.

College campus organizations also facilitate opportunities for South Asian youth to meet and socialize with one another. In the past two decades, numerous Indian student associations, South Asian student associations, Muslim and Hindu student groups have formed on college campuses throughout the United States. Northwestern University, DePaul University, Loyola University-Chicago, and University of Illinois-Chicago all have active South Asian student groups and Muslim and Hindu student organizations.

7 See Kniss and Numrich for further discussion of my research on marriage in the Chicago South Asian community.

8 Desi is a "slang" term used by South Asian immigrants to refer to South Asian members of the community or as a descriptive term used to describe South Asian activities, customs, foods or events. The term "desi" is used by South Asian immigrants when they speak to each other (rather than by non-South Asian immigrants). 


\section{Ethnic Studies Review Volume 31}

These universities organizations often arrange events and activities as well. Indian, Pakistani and Bangladeshi immigrant youth are able to meet each other at university-sponsored events without family intervention or supervision.

Historically, ethnic and religious organizations were used by parents and elders in the community to organize social events for youth and college-aged students. However, more recently second-generation youth have taken it upon themselves to create organizations and arrange social gatherings where they can meet other South Asian immigrants without parental supervision. Organizations such as Netip (the Network of Indian Professionals) and CAMP (Council of American Muslim Professionals) were founded by second-generation South Asian immigrants primarily for social networking with other South Asian professionals. My respondents also spoke of organizations catering to Indian immigrants from specific regions. Other religiously based immigrant organizations such as KCYLN (Knanaya Catholic Youth League of North America), or ISNA (Islamic Society of North America) have sponsored singles events at their annual conferences. These organizations host dinners, picnics and annual conferences and are often used as arenas for introductions by parents as well as other family members and friends. One South Asian Muslim woman spoke of how eager her parents were for her to attend ISNA every year in hope of her getting introduced to a suitable partner. She mentioned that most of these introductions were done by parents.

Several of my student respondents spoke of these groups as a format to meet a potential spouse. Shehnaz, a Pakistani Muslim woman explained, "I know that some families come to these things hoping their kids will meet someone. I'm sure it has been successful for some... I do know people who go there for that purpose." Farheen, an Indian Muslim woman, described ISNA as a "meat market" for single Muslims. She understood that conventions were often an ideal place to meet other single South Asian immigrants but viewed conventions as a "meat market" because single women were judged based on physical attractiveness. Tahira, a Muslim respondent, explained that the emphasis on women to marry was 
much stronger than it is for South Asian immigrant men:

Young women have a lot more pressure placed upon them to get married while they're still "young and beautiful" and therefore, "marriageable," whereas young men do not have to worry because there will always be more young women available for them to marry. A woman's ability to get married is inversely correlated with her age. It is almost a bad omen to have an unmarried female who is over 30 years of age living in a South Asian home.

In addition to physical beauty, age was a common theme that Tahira and other female respondents mentioned. South Asian immigrant women are under heavy pressure to marry in their early to mid-twenties. In the South Asian community, getting a young woman married by her mid-twenties is just as important if not more so, than educating her, a sentiment that is shared by both South Asians and South Asian Americans. Women that I interviewed spoke of "marriage pressure" that they felt after they turned 20. One Indian Muslim woman, Sanah, spoke of her engagement at age 19. Rekha, a Hindu woman, discussed her parents' constant nagging about marriage even though she had become financially independent and could support herself. Of course marriage is also important for South Asian immigrant men and their families, especially as they approach the age of 30 . One young Muslim man, Tariq, spoke of his parents' concern over his 29 year-old brother: "They are obsessed with my brother right now. He's almost 30. They are about to lose their mind." Many of my respondents shared similar stories. Parents felt that getting their children married was a high priority in the Indian and Pakistani immigrant communities.

\section{The Arranged Marriage}

There are three patterns that I observed in terms of how South Asian immigrants are getting married: arranged marriages, semiarranged marriages, and "love" marriages which refer to dating. Though the thought of an arranged marriage may seem strange and backwards to many Americans, it is still a common phenomenon 


\section{Ethnic Studies Review Volume 31}

in many South Asian immigrant families. Purkayastha's work highlights that the arranged marriage continues to be negatively associated with oppressed South Asian women. "The imagery is based on the stereotype that the typical South Asian American female is one who is forced into arranged marriages and controlled through veiling, payment of dowry, and other customary practices" (Purkayastha 2005, 41). However my data demonstrates that there are several reasons why South Asian immigrants may choose to have an arranged marriage including the following: the maintenance of culture, as a safeguard against premarital sex and dating, as a way to appease family and community, and lastly as a strategy to find a mate as a "final resort" after failed attempts at dating. Many immigrant families interpret the arranged marriage as the key to maintaining religious and ethnic tradition. Marriage in Indian society symbolizes religious and ethnic meaning. Marriage is one means of the maintenance of ethnic and religious traditions, and maintaining the cultural purity of an immigrant group.

The arranged marriage also functions as a safeguard against dating, and protects youth from sexual promiscuity and premarital relations ${ }^{9}$. A third reason for the prevalence of arranged marriages is that some South Asian immigrants place great importance on their parents ${ }^{\prime}$ wishes, often over their own personal preferences ${ }^{10}$. Lastly, I also argue that other immigrants, especially South Asian immigrant women, see it as a final way of finding a marriage partner; if they do not find their own spouse by a certain age, they would rather let their parents find them a mate than remain single. This often happens after a slew of unsuccessful dating relationships, or with those immigrants that feel too shy or introverted to look for their own mates. However, the factors that influence individual choices include family involvement, ethnic community, and religious ideology. These themes cross religious traditions.

The arranged marriage is a way to ensure the transmission of ethnic and religious ideas, morals, rituals and traditions:

9 Foner also found that arranged marriages can be seen in a positive light as a way "to avoid the frightening American dating scene, involving premarital sex and potential rejection" (Foner1997, 965).

10 Foner and Lessinger both found that young people submit to arranged marriages largely because of their parents' wishes (Foner 1997, Lessinger 1995). 
Marrying the 'right kind' of Indian is believed to preserve the culture from dilution, insuring the reproduction of Indian progeny and the re-production of Indian culture. It is for this reason that the arranged marriage is still a viable option for Indian Americans (Mukhi 2000, 64).

This idea transcends Indian culture to Pakistani and Bangladeshi immigrant society as well. Similarly, South Asian families that promote the arranged marriage often believe that arranging children's marriages will protect them from American dating rituals, premarital relations and promiscuity. Gupta (1999) suggests that, "the traditional arranged marriage, with no input from the young people involved, is a system to control young women and keep them within parentally ordained boundaries," and this is one reason that the arranged marriage remains a common practice even in immigrant communities (110). The arranged marriage is often more strongly encouraged for South Asian women than for men. Leonard (1997) explains:

Another perceived threat to family life in the United States is the more open sexuality. South Asians generally place more emphasis on women's virginity at marriage, a goal achieved by arranged marriage for the brides and grooms at fairly young ages in South Asia but achieved more recently by prevention or control of dating (1997).

Therefore those families that promote arranged marriages strongly discourage dating.

My interviews and conversations indicate that the arranged marriage is still a common option for finding marriage partners in Hindu, Muslim and Indian Christian immigrant communities. The reasons supporting the arranged marriage as cited in my interviews were to maintain chastity until marriage by religious conservatives, maintain ethnic and religious ties for those tied to family and community, and as a final option for finding a marriage partner for liberal and cultural immigrants. Two Muslim immigrant 


\section{Ethnic Studies Review Volume 31}

women in particular were open to the arranged marriage as a way of safeguarding themselves from any sexual relationships before marriage. Muslim, Christian and Hindu second-generation immigrants spoke of the arranged and semi-arranged marriage as ways to maintain ethnic and religious traditions. Three Muslim women and two Hindu women claimed that they saw the arranged marriage as a last resort, if they did not find partners before their late twenties.

As I mentioned before, acceptance of the arranged marriage was common amongst Hindu and Muslim immigrants. Four of the fifteen Hindu immigrants and eight of the twenty-six Muslim immigrants favored the arranged marriage. Though none of the Christian Indian immigrants preferred the arranged marriage, seven out of nine of them favored the semi-arranged marriage. Christian immigrants also mentioned that the arranged marriage was a common practice in Indian Christian immigrant congregations and communities, but that was not the preferred way of getting married for Christian second-generation immigrants.

Numrich (2002) writes that "Hinduism favors arranged marriage over romantic or 'love' marriages" (311). In the Hindu community, the arranged marriage is common in conservative and liberal Indian families. In the Hindu American community, the arranged marriage remains an option because it helps maintain caste, religious, and ethnic ties. Cultural and liberal Hindus also said in their interviews that the arranged marriage is often a fall back for young immigrants who do not successfully find mates on their own.

Swaminarayan respondents cited maintenance of ethnic and religious ties as a key reason for opting for an arranged marriage. Williams discusses the important of ethnic identity maintenance for Swaminarayans: "Guajarati ethnicity is essential to personal and group identity in this group, which adopts an ethnic strategy of adaptation in the face of internationalization and modernization. The sect is formed on a regional-linguistic basis, and virtually all followers are Guajarati's" (Williams 1998, 852)." Therefore an arranged marriage ensures and reinforces both ethnic and religious endogamy for Swaminarayan Hindus. Radha, a 55 year Swaminarayan Hindu congregant, talked about the pitfalls of 
the love marriage in terms of values and lifestyles, affirming that Swaminarayans have a distinct way of life:

Even the love marriages are a failure. Why? Because they don't look into the practical life, the habits and stuff, everybody has their different values and different lifestyles the way they have been raised, so we make them understand you'll watch out for this you know it will not work out in the long run.

Radha explained that since the elders of the community had lived experience they were able to guide younger congregants in terms of marriage matters. She saw the arranged marriage as a way to maintain tradition and lifestyle, both ethnic and religious. Payal, a 45-year-old Swaminarayan Hindu women, affirmed that arranged marriages remained popular in this community: "Most of them are doing arranged marriages about $70 \%$, but there are some love marriages."

The arranged marriage is also still an option for some liberal South Asian Hindu women. Both Sushila and Meena, two culturally Hindu women, said that they did not prefer an arranged marriage but would not close it off as an option. Sushila specifically said she had been resisting an arranged marriage and had several serious relationships with non-Indians throughout college and graduate school. Her parents were adamant on her being open to their "introductions" to suitable Indian Hindu professional men. Sushila didn't think she was a primary candidate for arranged marriage because it felt so forced. She was also tired of the marriage pressure from her parents since she was quickly approaching age 30 . In the following excerpt, Sushila talks about her anxiety related to the arranged marriage process:

It's just a screwed up way of meeting people in my opinion when you are brought up with all this stimuli that teach you how love should happen or romance. It's not like I go out to bars to meet people. That's weird for me too. I'm friends with them and then whatever. It's just a slow process based on friendship. This introduction thing is so artificial and contrived. 


\section{Ethnic Studies Review Volume 31}

It ruins things. So I am sorta kind of going back. And then it's never simple as much as my parents are relatively progressive. Then the parents call my parents. And it's never as hands off as they say it is. Or as much as I want it to be. My Mom is a feminist, and my parents are pretty progressive. So I am now sort of going back to stop (stop them from arranging my marriage). But I don't want to tell them to stop cus it keeps them occupied.

Later in this same interview Sushila added that since she was now 28, combined with parental pressure, she had recently become more open to the arranged marriage again. Another Hindu woman, Meena, had also dated throughout college but said she would be encouraged to reconsider the arranged marriage option as she became older. In her interview she quoted her mother as saying, "But if you are not married by the time you are 28 then I'm going to find someone." Meena also viewed the arranged marriage as a last resort if she too did not marry by age 30 .

The arranged marriage remains popular amongst South Asian Muslim immigrants as well because it helps maintain religious and ethnic traditions, encourages chastity until marriage, and is an option for immigrant youth that do not find partners on their own. In Islamic cultures, the arranged marriage is also preferred because marriage has traditionally been viewed as a marriage between families, and marriage in Islam is viewed as a "religious duty" (Korson 1969, Numrich 2002). Islamic doctrine strongly promotes abstinence until marriage, and culturally South Asian Muslim families strongly emphasize premarital virginity, especially for girls and women. Several Muslim respondents cited chastity and modesty as a common reason for choosing an arranged marriage. One of the teachers at an Islamic School, Shireen, had an arranged marriage. Shireen wanted to get married but was not interested in dating. Her family initially met her husbands' family at an Indian Hyderabradi convention in the United States, and then arranged her marriage after several months. Naazneen, a single Indian Muslim woman, talked about her strong approval of the arranged marriage. She believed that it was the ideal way for a practicing Muslim to 


\section{Ternikar-To Arrange or Not}

meet a marriage partner. Naazneen also emphasized that modesty and premarital abstinence were two important factors in Muslim life, and she did not want to interact with her potential partner until after the marriage ceremony was performed. She did not want to even talk on the phone prior to marriage. Naazneen believed that talking on the phone was too intimate an activity to engage in before marriage.

Other Muslim women were also open to the arranged marriage option. Laila, an Indian Muslim woman, approved of the arranged marriage primarily because she trusted her parents, and did not want to disrespect them; she explained: "Personally I believe yes my parents will do what's best for me. However, I should have a say in it and know the person before I get married". Another single Muslim woman, Tahira, felt torn between having an arranged marriage and getting to know her potential mate; she said, "and I wouldn't mind probably being alone with him, but I guess Islamically that wouldn't be right. Islamically I shouldn't be alone with a man (before I marry him)". Tahira wanted to get to know her suitor before she got engaged, but she also felt that morally it was not right for her to spend time with him alone before they were married.

In my focus group with four young Muslim Indian women, the single women spoke of the arranged marriage as a last resort with responses similar to the single Hindu women with whom I spoke. They said that they hoped they would be able to find mates on their own through their own peer networks and hoped that they would know their spouses before marriage. Dahlia, one of the Indian Muslim women, said:

I need to know who I am marrying... ideally I'd like to be friends with the person first, l'd like to find the person on my own .. if I knew him really well I would treat the Nikah as dating and do that for a year and a half.

Dahlia hoped to know her husband on a platonic level before she got married, and explained that she would want to date her husband after performing a Nikah, the religious marriage 


\section{Ethnic Studies Review Volume 31}

ceremony.

Each of the Christian Indian respondents also spoke of the continued practice of arranging marriages in the American context. Conservative Christian Indian theology further promotes the arranged marriage as it advocates chastity until marriage. Indian Christians also mentioned the maintenance of ethnic ties as a reason for choosing arranged marriages. As Nita, an Indian Christian woman, explained:

Arranged marriage is the thing. If you have a love marriage you need to make sure that the guy is from a good family or he's from the same religion as you are the same denomination as you are. Make sure your parents know about it. You know how it is, with a love marriage, they go crazy. And mainly they should see how the family is. That makes a big difference. The guy if he's settled, the guy he's fine and the family if they've got a big name, and stuff like that. Arranged marriages are more common.

Nita explained that in her family's Indian community, love marriages were accepted if two conditions were met: that the marriage was endogamous, in terms of religion and ethnicity, and the family was seen as respectable and honorable within the community. Obviously, parents had more control in making sure their children had suitors from a "good family" and maintaining religious endogamy if the marriage is arranged. Another Indian Christian woman, Sapna, mentioned that she was comfortable with having her parents find a marriage partner for her because she wanted to marry within the Malayalam ethnicity and the Catholic faith. For her, it was not a strong possibility that she would be able to find a partner without her parent's assistance and community ties. In addition, she mentioned that she trusted her parents' judgment in finding her a partner, and they had allowed her to reject suitors in the past.

Williams (1996) writes of the prevalence of the arranged marriage amongst Indian Christian churches and specifically amongst the Knanaya Christians. The Knanaya Christians have 
strict rules regarding racial and religious endogamy (Ternikar, 2008). The arranged marriage helps preserve endogamy within the church community. He does note the exception of the Brethren Christians who allow dating if it is within the congregation. My informal conversations with Indian youth at the Brethren congregation also reflected the prevalence of both arranged marriages and dating.

The arranged marriage is still a common practice in the South Asian immigrant communities, especially among Muslim and Hindu immigrants. Twenty-four percent of the respondents in my sample were either in an arranged married or preferred to have an arranged marriage. None of the Christian respondents in my sample were in an arranged marriage, but more than half of them favored a "semi-arranged" marriage over a "love marriage" (see Table 1). The proponents of the arranged marriage tend to be Hindu, Muslim or Christian immigrants who are concerned with maintaining traditions, ethnic and religious. Many conservative Christian and Muslim immigrants also practice arranged marriages to discourage pre-marital sexual relations. The hesitant supporters of the arranged marriage are those single Hindu and Muslim immigrants who consider the arranged marriage as a final alternative. Finally, parents often support the arranged marriage because of their vested interest in maintaining strong family ties (Numrich 2002).

Race, ethnicity, class and religion all play significant roles in the marriage equation for arranged and non-arranged marriages in the South Asian immigrant community. Though often discouraged by family and community, "love marriages" and semi-arranged marriages are increasing in the South Asian community.

\section{The Love Marriage}

The alternative to the arranged marriage has historically been the "love marriage." "Love marriage" is the term used by South Asian immigrants and South Asians to describe marriage that developed out of dating or a romantic. However, as mentioned previously, dating is still somewhat looked down upon, especially when South Asian immigrant women are involved. South Asian immigrant women are strongly encouraged to maintain ethnic traditions; the 


\section{Ethnic Studies Review Volume 31}

arranged marriage is an example of an ethnic tradition that women are more harshly judged for rejecting. Indian women in the Diaspora are largely seen as the keepers of ethnic and religious tradition 11 (Maira 1999, Dasgupta and Das Dasgupta 1997). However, "Second-generation youth appear to be reproducing their parent's policing of ethnic boundaries in certain instances, a surveillance that often has a specifically gendered edge with a keen focus on women's behavior, particularly in sexuality" (Maira 1999: 49). This gendered understanding of dating and sexual norms is largely linked to social norms that have been reinforced by first generation South Asian immigrants (Gupta 1997). More educated women in India, according to previous studies, and in this study are more likely to have a love-marriage than an arranged marriage (Corwin 1977). In addition, dating is somewhat more acceptable in certain liberal Hindu and Christian immigrant communities than in Muslim immigrant communities. Dating is a place where religious norms are used to reinforce conservative gender and sexual norms.

Strict gender and sexual norms, along with family and community pressure, strongly discourage Muslim youth from dating openly. One of the reasons that first-generation parents of many South Asian immigrants discourage dating is because it is equated with sexual promiscuity. Nevertheless, dating does occur in all three religious traditions. Dating practices are contingent on family, religious ideology and ethno-religious community.

Five out of the thirteen Hindu women that I interviewed mentioned present or past dating relationships. Another two women talked about love marriages in the family. Saman, a Hindu Indian woman, even described her parents' marriage as a love marriage:

They eloped. Long story--my Mom was arranged to be married to someone else she came home and was like wait Mom and Dad I met somebody and we've been together for 2 years and

11 In Maira's study of South Asian subculture in New York City, she found that, "Women are expected to carry the burden of embodying unsullied tradition, of chaste Indian womanhood, as has been pointed out in the discussions of the double standard that applies to sexual behavior for young South Asian American women as opposed to men" (Maira 1999:49). 
he's leaving for England, and so my Mom said surprise I'm moving to England and that was a big no-no, totally mismatch of caste, wealth, and status, my Mom is My dad is South Indian and my Mom is North Indian, and it was just a huge cultural clash so they just eloped. I think ever since then they never believed in saying this is who you actually should be with.

Saman's experience was an anomaly. But since Saman's parents had not had an arranged marriage, they did not expect Saman to have one either. Manjaree, another Hindu woman, also spoke about her dating experiences. She also explained that her parents were divorced and did not have a lot of control on her personal life:

No my Mom has always been very open and she has given me a lot of freedom, she always said you can start dating when you are 21 kind of.

And then I started dating when I started college. I did tell her. I was interested and I am going to start dating. I have never dated anyone Indian. I have three relationships and they have all been with white guys. And she's known of all three of them.

The other Hindu respondents explained that arranged marriages were definitely commonplace in their parents' generation in India. Though a few of my respondents spoke of dating, the arranged marriage was still an option even for second-generation Hindu immigrants. Three of the BAPS Swaminarayan congregants spoke of dating for the purpose of marriage as permissible only after completing higher education. Veena, a BAPS Swaminarayan congregant, explained:

Well our religion teaches you should only date after you finish your education, and if you do date after you are done with your education, it should be for the sole purpose of getting married. So with the people I usually hang around, that's what they believe... actually our temple has this national biodata and it has names of each person, well whoever wants to participate 


\section{Ethnic Studies Review Volume 31}

in it, and when its time to get married you can submit a biodata if you want.

Veena and other congregants also spoke of the arranged marriage as the preferable method in finding a marriage partner at the BAPS temple. The biodata database at the temple kept a catalog of single BAPS Swaminarayan congregants. "Biodata" refers to a resume of sorts that includes a single individual's educational background (sometimes including salary), family history, caste, birthday and often a picture. Not all religious congregations have a biodata database, but for Hindu and Muslim immigrant families with single children exchanging biodata is a common practice, and often the first step of arranging a marriage.

Though the arranged marriage is largely promoted by Muslim immigrant congregations, dating also occurs in the Muslim South Asian community, but is considered a social taboo largely because of religious doctrine which is reinforced by the larger ethnic family and communities. One Indian Muslim woman, Adeela, explained that most of her dating relationships had been kept secret from her parents. Ultimately, her parents hoped to arrange her marriage, but she was able to find Muslim men to date in hopes of finding her own marriage partner. Adeela did not think anything was "unlslamic" about dating, as long as she was dating a Muslim man. She mentioned that she had dated a few guys: "My friend made me go on a blind date last weekend - he was really nice and he goes to law school, good guy. I just wasn't attracted". Tariq, a Muslim Indian man, also spoke of dating, and was the only Muslim respondent who spoke of his family's approval of dating. Tariq explained that he saw dating as part of his "liberal," non-practicing past in high school and college. His dating experiences had been primarily with non-Muslim women. He added that he no longer dated since he had become a "practicing" Muslim because he now thought dating to be wrong:

The other day my Dad asked me why I don't have a girlfriend.

I was like Dad, I went through that phase in undergrad and I kind gave up dating when I realized it just wasn't, that was 
another thing that wasn't bringing any peace of mind. But my parents just can't seem to understand that concept, as long as it involves a Muslim girl (they want me to date), now if it's a non-Muslim girl then it's completely non-acceptable (to date or marry).

Tariq hoped to find a marriage partner through a friendship network with the hopes of remaining platonic until marriage. Other Muslim respondents did not speak about their own dating experiences but mentioned siblings, friends, and cousins who had dated. All of my respondents including the Islamic School principal and administrators did acknowledge that dating is becoming a more common occurrence in the Muslim immigrant community even though it is strongly discouraged.

Dating is prevalent in some Indian Christian communities if it is endogamous racially and religiously. One Catholic Indian woman, Mary, explained that arranged marriages are still common in her community but that some more liberal families such as hers did allow dating: "In the community it's mostly arranged, but like some parents are more liberal than others, like mine, like my parents are like as long as the guy is Indian Christian". Mary added that her family's Indian community is conservative and does not promote dating. Her parents have made an individual decision to allow her to date as long as she dates another Indian Christian. Another Catholic man, Joseph, talked about his dating process as well. Joseph said that his parents did try to arrange his marriage and they were not successful. He eventually met a white woman at his church and they dated before marrying. Joseph's parents were pleased that he had at least married a Catholic woman.

Dating remains a somewhat contentious topic in the South Asian immigrant community. Perhaps, dating will increase as more second and third generation immigrants are socialized in the United States. Dating is less common in religiously conservative communities of any South Asian traditions. Conservative religious congregations of Catholic, Hindu and Muslim backgrounds do not promote dating because it is a threat to religious and ethnic tradition. Some liberal South Asian families do allow dating. In 


\section{Ethnic Studies Review Volume 31}

addition, there are South Asian immigrants who continue to date without family or community approval.

Of the people I interviewed (15 Hindus, 26 Muslims, 9Christians), Hindu immigrants have the highest rate of approval of dating and love marriages. Nine out of fifteen of the Hindu immigrants I spoke with either had dated, were dating, or approved of dating as a method of getting to know a potential marriage partner. Only two of the twenty-six of the Muslim immigrants approved of dating or the love marriage. However, more than half, sixteen out of twentysix, of the Muslim immigrants supported semi-arranged marriages.

None of the Christian immigrants I interviewed favored or were married through a strictly arranged marriage. Seventy-eight of the Christian immigrants preferred or had been married through a semi-arranged marriage, while two of the nine Christian immigrants favored or had dated before getting married.

\section{To arrange or not to arrange: The creation of the "semi-arranged" marriage}

I don't know if there are truly that many arranged marriages per se, meaning... Some third party elder says this person is for you and you are for this person and you get married. I think the more appropriate term in today's day and age in India and here is arranged introductions.

In the above quote, Rajiv, a male Hindu immigrant introduces "arranged introductions". Are the alternatives to the arranged marriage such as "arranged introductions" replacing tradition? With the increase of South Asian immigrants in the United States since 1965 and the popularity of the Internet, new alternatives to the arranged or love marriage are possible. The most popular options that my respondents spoke of included arranged introductions or "semi-arranged marriages" and on-line services.

Arranged introductions also known as semi-arranged marriages include those situations where parents, relatives, family friends, or community members are involved in introducing their children to suitable or appropriate mates. The daughter or son can get to know 
the potential mate by talking on the phone, through exchanging emails, and/or via group dates with chaperones. The semi-arranged marriages are encouraged by the children themselves because they do not want to date, yet they do not want parents strictly arranging their marriages. In addition, because many immigrant children have been socialized by notions of romantic love, they want to know their potential mates before they get married. But the semiarranged marriage process does not encourage any premarital sexual relations. Partners in this process do not necessarily have a physical relationship before their wedding, often for religious reasons and sometimes for cultural ones.

In my research I found the semi-arranged marriage was always between two people of the same pan-ethnic and religious background. It is a way for second-generation immigrants to find like-minded partners. The youth that preferred a semi-arranged marriage were often religious but not necessarily cultural. They wanted to feel like they were involved in the marriage process and that they had some level of autonomy and agency ${ }^{12}$.

Semi-arranged marriages were also a useful way for religious immigrants to find partners. One concern that young women spoke about was trying to find a partner that was at the same "religious level." By speaking on the phone and emailing before marriage, young women are able to ask potential mates serious questions about religious values and practices. Shahista and Obed, a young Muslim couple, spoke of their marriage as a semi-arranged marriage. They were introduced to each other by a mutual Muslim friend, and they began to get to know each other by talking on the phone and going on chaperoned social outings. After six months of interacting, they were married.

The semi-arranged marriage allows for some level of freedom, romance, and self-selection without any physical intimacy before marriage. The semi-arranged marriage was the most popular option in my sample. Half of my entire sample preferred the "semiarranged" marriage over the arranged-marriage or the love marriage. The "semi-arranged" marriage is popular among second-generation

12 Foner highlights that the interplay between "culture, structure, and agency" is significant for understanding how immigrants reconstruct marriage and family patterns in the context of the American environment (Foner 2005, 165). 


\section{Ethnic Studies Review Volume 31}

immigrants because it satisfies parents' requirements of endogamy, and it gives children a sense of autonomy. Noor explained that she wanted to have a "friendship" with her partner before she married him. She felt that if they talked on the phone and exchanged emails before they got married, she would get a chance to know him. The semi-arranged marriage also results in endogamous marriages. Therefore, it also helps maintain ethnic and religious traditions while also giving children agency in the marriage process. This method ultimately satisfies second-generation children and their immigrant parents.

Matrimonial on-line services are an option for South Asian immigrants as well. On-line services often help facilitate arranged and semi-arranged marriages. Parents and siblings look on-line also for mates for single family members. Single individuals also initiate relations through these sites. Popular matrimonial websites for South Asian immigrants include matrimonials.com, indianmarriages. com, indianlink.com and suitablematch.com. Through these sites South Asian singles are able to search databases for ideal matches. Characteristics most often included in these singles advertisements include ethnicity, religion, age, immigration status and education level. Another appeal of on-line marriage services is that it often decreases the involvement of parents and family in the arranged marriage process, where single people can look for appropriate matches on their own and make initial contact with potential partners without a chaperone. This alternative continues to grow in popularity as new online dating and marriage sites targeting South Asian immigrants continue to develop. One of my respondents, a Christian Indian, mentioned that he used an online dating service, match.com, in hopes of finding a marriage partner. Noor, a Muslim respondent, explained that many of her friends had recently joined naseeb.com in hopes finding a potential Muslim match. Perhaps in the near future, matrimonial web sites will cause a decrease in traditional arranged marriages in the United States.

More second-generation South Asians are dating or semiarranging their marriages. However, the truly "arranged marriage" where parents select a mate for their children is still a practice in immigrant communities in the United States. In Rangaswamy's 
(2000) study of Chicago Indian immigrants $71 \%$ of her respondents approved of arranged marriages (181). This most likely will remain a practice in South Asian immigrant communities because it allows parents to have great involvement in the selection of their children's' spouse, while ensuring the maintenance of ethnic and religious tradition and racial purity.

\section{Discussion of Data and Conclusion}

According to this research, dating and the love marriage is more common for Hindu immigrants than for Muslim or Christian immigrants, and the arranged marriage is more common among Muslim immigrants, than for Hindu or Christian immigrants. ${ }^{13}$ Both Muslim and Christian immigrants prefer the semi-arranged marriage over the arranged-marriage or dating option. Dating may not be a popular option for Muslim or Christian South Asian immigrants because it more likely results in exogamous marriages. In the case of Muslim immigrants, dating is also discouraged because of conservative gender and sexual norms that are reinforced by ethnoreligious communities particularly for Muslim women (Schmidt

13 This analysis becomes more complicated when I separate those immigrants who label themselves as liberal or cultural from those immigrants who label themselves as conservative or "practicing". Eleven out of 15 of the Hindu immigrants considered themselves to be cultural liberal Hindus. Two of the 26 Muslims claimed that they were cultural Muslims rather than religious Muslims. Four of the 9 Christian immigrants I interviewed also claimed that they identified with liberal Catholicism. When I compared liberal immigrants to conservative immigrants, I found that none of the liberal immigrants preferred the arranged marriage. Five out of eighteen of the liberal immigrants supported or were in a semi-arranged marriage, and more than half (thirteen out of eighteen) of the liberal immigrants preferred a love marriage. Out of the thirty-two conservative immigrants, only two preferred a love marriage, eighteen preferred a semi-arranged marriage, and twelve preferred an arranged marriage. I can hypothesize that in my sample, liberal immigrants prefer dating as a method to getting married while conservative immigrants prefer the arranged or "semiarranged" marriage option. Conservative immigrants interpret arranged marriages as a way to safeguard religious and cultural identities. In addition, I found the semi-arranged option to be popular amongst conservative immigrants regardless of religious tradition and particularly with Christian and Muslim immigrants (see table 1). These findings reinforce the idea that for religious reasons, conservative South Asian immigrants, Christian and Muslim immigrants prefer semi-arranged and arranged marriages to the love marriage option because it facilitates religious endogamy. 


\section{Ethnic Studies Review Volume 31}

2004).

Lastly, arranged marriages are a way to retain ethnic and cultural traditions. Traditional practices of marriage carry meanings of ethnic and religious authenticity even to second-generation South Asian immigrants. The semi-arranged marriage is a significant creation of a new marital norm that allows for the maintenance of ethnic and religious traditions but also appeases second-generation immigrants in their pursuit of personal happiness or romantic love. Secondgeneration immigrants interpret the semi-arranged marriage as a way to maintain their cultural identities while also gaining the approval of their families and ethno-religious communities.

However, this research highlights that religion matters significantly in these marital decisions ${ }^{14}$. This was clearly evident in the comparison of religiously conservative Hindus, Muslims, and Christians with religiously liberal Hindus, Muslims, and Christians. The arranged and semi-arranged marriages remain popular because they are both ways that help conservative immigrants find partners within their religion. Only two of the conservative immigrants favored a love-marriage over a semi-arranged or arranged marriage. Yet, none of the liberal immigrants preferred an "arranged marriage". Religious conservativism influences the marriage choices for South Asian immigrants. Comparing immigrants from the three traditions, I found Muslim immigrants to have the highest number of arranged marriages, and the lowest number of love marriages. In addition, Hindu immigrants had the highest number of love marriages. This is most likely so because unlike Indian Catholics and South Asian Muslims, Hindu immigrants do not have any specific religious codes on exogamy (Lawrence 2002, Courtright and Harlan 1995). Islam and Catholicism are both religious traditions based on religious law and scripture-based norms ${ }^{15}$. Acceptance of exogamous marriage in Hindu families is often contingent on level of religiosity, sect, caste, class, region of origin and educational level (Bacon 1996,

14 Kurien's research on Indian immigrants in the United States also highlights the importance of religious identity for Indian immigrants. Her research focuses on Hindu and Muslim immigrants (1997 and 2001).

15 For Muslims, Islamic law (Shariah) based on Hadith and Quran clearly outlines that Muslim men can marry women of the book (Muslim, Jewish or Christian) but Muslim women must marry within the faith. 
Courtright and Harlan 1995, Fenton 1988). The practice of Hinduism varies greatly between regions of India (Courtright and Harlan 1995, Fenton 1988).

An extended discussion of arranged marriage practices highlights the great emphasis in South Asian immigrant communities to maintain endogamy for both ethnic and religious reasons. However, this research also suggests that religious tradition or religiosity (conservative versus liberal) does influence how some South Asian immigrants marry. Future research should emphasize changes in who immigrants actually marry, particularly along religious lines as third-generation immigrants come of age. This future research should also develop a comparative analysis within the community among class-lines.

\section{Table 1:}

Relationship between Religion and Method of Marriage

\begin{tabular}{|l|c|c|c|c|}
\hline Religion & Arranged & Semi-arranged & Love & Total \\
\hline \multirow{2}{*}{ Hindu } & $27 \%$ & $13 \%$ & $60 \%$ & $100 \%$ \\
& $\mathrm{~N}=4$ & $\mathrm{~N}=2$ & $\mathrm{~N}=9$ & $\mathrm{~N}=15$ \\
\hline \multirow{2}{*}{ Muslim } & $31 \%$ & $61 \%$ & $8 \%$ & $100 \%$ \\
& $\mathrm{~N}=8$ & $\mathrm{~N}=16$ & $\mathrm{~N}=2$ & $\mathrm{~N}=26$ \\
\hline \multirow{2}{*}{ Christian } & 0 & $78 \%$ & $22 \%$ & $100 \%$ \\
\multirow{2}{*}{ Total } & $\mathrm{N}=0$ & $\mathrm{~N}=7$ & $\mathrm{~N}=2$ & $\mathrm{~N}=9$ \\
& $\mathbf{2 4 \%}$ & $\mathbf{5 0 \%}$ & $\mathbf{2 6 \%}$ & $\mathbf{1 0 0 \%}$ \\
& $\mathbf{N}=\mathbf{1 2}$ & $\mathbf{N}=\mathbf{2 5}$ & $\mathbf{N}=\mathbf{1 3}$ & $\mathbf{N}=\mathbf{5 0}$ \\
\hline
\end{tabular}

Table 2:

\begin{tabular}{|l|c|c|c|c|}
\hline Religion & Arranged & Semi-arranged & Love & Total \\
\hline \multirow{2}{*}{ Conservative } & $38 \%$ & $56 \%$ & $6 \%$ & $100 \%$ \\
& $\mathrm{~N}=12$ & $\mathrm{~N}=18$ & $\mathrm{~N}=2$ & $\mathrm{~N}=32$ \\
\hline \multirow{2}{*}{ Liberal } & $0 \%$ & $28 \%$ & $72 \%$ & $100 \%$ \\
& $\mathrm{~N}=0$ & $\mathrm{~N}=5$ & $\mathrm{~N}=13$ & $\mathrm{~N}=18$ \\
\hline \multirow{2}{*}{ Total } & $\mathbf{2 4 \%}$ & $\mathbf{4 6 \%}$ & $\mathbf{3 0 \%}$ & $\mathbf{1 0 0} \%$ \\
& $\mathbf{N}=\mathbf{1 2}$ & $\mathbf{N}=\mathbf{2 3}$ & $\mathbf{N}=\mathbf{1 5}$ & $\mathbf{N}=\mathbf{5 0}$ \\
\hline
\end{tabular}




\section{Ethnic Studies Review Volume 31}

\section{REFERENCES}

Arber, Sara. 1993. "Designing Samples" In Researching Social Life, ed. Nigel Gilbert, 255-269. London: Sage Publications.

Bacon, Jean. 1996. Life Lines: Community, Family and Assimilation among Asian Indian Immigrants. New York: Oxford University press.

Bradley, David. 1983. "Duress and Arranged Marriages." The Modern Law Review. 46 (4): 499-504.

Corwin, Lauren A. "Caste, Class and the Love-Marriage: Social Change in India" Journal of Marriage and the Family 39: 823831.

Courtright, Paul B. and Lindsey Harlan. Eds. 1995. From the Margins of Hindu Marriage: Essays on Cender, Religion and Culture. New York: Oxford University Press.

Dasugupta, Sayantani and Shamita and Dasgupta. 1997. "Women in Exile: Gender Relations in the Asian Indian community". In Contours of the Heart: South Asians map North America. Sumaina Maira and Rajini Srikanth, eds. Pp. 381-400. New York: Asian American Writer's Workshop.

Fenton, John Y. 1988. Transplanting Religious Traditions: Asian Indians in America. New York: Prager Publishers.

Foner, Nancy. 1997. "The Immigrant Family: Cultural Legacies and Cultural Changes." International Migration Review 31(4): 961974.

Foner, Nancy. 2005 "The Immigrant Family: Cultural Legacies and Cultural Changes" in The New Immigration, eds. Orozco, Orozco and Quin. New York: Routledge.

Gans, H.J. 1979 "Symbolic ethnicity: the future of ethnic groups 
Ternikar-To Arrange or Not

and cultures in America. Ethnic and Racial studies 2 (1):1-20.

Gupta, Monisha Das. 1997. "What is Indian About You: A Gendered, Transnational Approach to Ethnicity." Gender and Society 11: 572-596.

Gupta, Sangeeta. 1999. "Walking on the Edge: Indian American Women Speak Out on Dating and Marriage." In Emerging Voices: South Asian Women Redefine Self, Family and Community, ed. Sangeeta Gupta, 120-45. Walnut Creek, CA: AltaMira Press.

Jana, Rana. 2000. "Arranged Marriages, Minus the Parents". New York Times Online, August 1 15t. Retrieved October 15, 2003. Kniss, Fred and Paul D. Numrich. 2007. Sacred Assemblies and Civic Engagement: How Religion Matters for America's Newest Immigrants. New Brunswick, NJ: Rutgers University Press.

Korson. 1969. "Student Attitudes toward mate Selection in a Muslim Society: Pakistan". Journal of Marriage and the Family. 31(1):153-165.

Kurien, Prema, "Becoming American by Becoming Hindu: Indian Americans Take Their Place at the Multicultural Tabel", in: R. Stephen Warner, Judith G. Wittner (eds.), Gatherings in Diaspora. Religious Communities and the New Immigration, Philadelphia: Temple University Press, 1998: 37-70.

Kurien, Prema, "Religion, Ethnicity and Politics: Hindu and Muslim Indian Immigrants in the United States", in: Ethnic and Racial Studies, 24, 2, 2001: 263-293

Lawrence, Bruce B. 2002. New Faiths, Old Fears: Muslims and Other Asian Immigrants in American Religious Life. New York: Columbia University Press.

Leonard, Karen. 1997. The South Asian Americans: New Americans 


\section{Ethnic Studies Review Volume 31}

Series. Westport, CT: Greenwood Press.

Leanard, Karen. 2003. Muslims in the United States: The State of Research. New York: Russel Sage Foundation.

Lessinger, Johanna. 1995. From the Ganges to the Hudson: Indian immigrants in New York City. Needham Heights, MA: Allyn \& Bacon.

Macdonald, K. and Tipton, C. 1993. "Using Documents." In Researching Social Life, ed. Nigel Gilbert. 58-72. London: SAGE.

Maira, Sumaina. 1999. "Identity Dub" The Paradoxes of an Indian American Youth Subculture (New York Mix." Cultural Anthropology 14(1): 29-60.

Mody, Pervez. 2002. "Love and the Law: Love-Marriage in Dehli." Modern Asian Studies 36 (1): 223-256.

Mukhi, Sunita. 2000. Doing the Desi Thing: Performing Indianess in New York. New York: Garland Publishing.

Numrich, Paul, D. J. Wall, D. Browning, W. J. Doherty, and S. Post. 2002. Marriage, Health, and the Professions: The Implications of New Research into the Health Benefits of Marriage for Law, Medicine, Ministry, Therapy, and Business. Grand Rapids: Eerdmans Publishing Company.

Purkayastha, Bandana. 2005. Negotiating Ethnicity. New Jersey: Rutgers University press. Rangaswamy, Padma. 2000. Namaste America: Indian Immigrants in an American Metropolis. University Park: Pennsylvania State University Press.

Schmidt, Garbi.2004. "Islamic Identity Formation Among Young Muslims: The Case of Denmark, Sweden, and the United States." Journal of Muslim Affairs 24 (April) 31-25. 
Ternikar, Farha. "Indian Christians and Marriage Patterns" forthcoming in 2008 in (eds) Selva J. Raj and Knut A. Jacobsen. South Asian Christian Diasporas: Invisible Diasporas in North America and Europe. UK: Ashgate Publishing.

Warner, R. Stephen and Judith G. Wittner, eds.1998. Gatherings in Diaspora: Religious Communities and the New Immigration. Philadelphia: Temple University Press.

Weiss, Robert. 1994. Learning from Strangers. New York: Free Press.

Williams, Raymond Brady. 1992., ed. A Sacred Thread: Modern Transmission of Hindu Traditions in India and Abroad. New York: Columbia University Press.

Williams, Raymond Brady. 1996. Christian Pluralism in the U.S.: The Indian Immigrant Experience. Cambridge: Cambridge University Press.

Williams, Raymond Brady. 1998. "Training Religious Specialists for a Transnational Hinduism: A Swaminarayan Training Center" Journal of the American Academy of Religion 66: 841-862. 